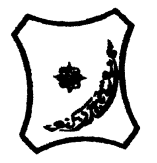

Bayero Journal of Pure and Applied Sciences: 10(1): 231 - 233

ISSN $2006-6996$

\title{
EFFECT OF CHRONOMODULATED ARTESUNATE ON SOME BIOCHEMICAL PARAMETERS IN METHOTREXATE TREATED ALBINO MICE
}

\author{
Mohammed, M. ${ }^{* 1}$, Labaran, K.S. ${ }^{1}$, Wada, A.S. ${ }^{2}$, Mustapha, S. ${ }^{3}$, Aliyu, I.M. ${ }^{3}$, Ahmadu, \\ J.0. ${ }^{4}$ \\ 1Department of Clinical Pharmacy and Pharmacy Practice, Ahmadu Bello University Zaria \\ ${ }^{2}$ Department of Pharmacology and Therapeutics, Bayero University Kano \\ ${ }^{3}$ Department of Pharmacology and Therapeutics, Ahmadu Bello University Zaria \\ ${ }^{4}$ Department of Pharmaceutical and Medicinal Chemistry, Ahmadu Bello University Zaria \\ *Corresponding Author: +2348036840137; macreener88@gmail.com
}

ABSTRACT

Methotrexate (MTX) and Artesunate (ART) co-administration is common during chemotherapy with malaria co-infection. Hepatotoxicity from these drugs have been linked to in part, the alterations in essential biochemical processes. Chronomodulation may improve the safety of these drugs even in concurrent use. This study was designed to investigate the effect of time of administration of MTX and ART on some biochemical parameters of the liver in mice. Mice $(18-20 \mathrm{~g})$ were treated intraperitoneally with $M T X 30 \mathrm{mg} / \mathrm{kg}$ and $A R T 30 \mathrm{mg} / \mathrm{kg}$ as either MTX9am, MTX9pm, MTX9pm-ART9am, MTX9pm-ART9pm and corresponding Normal Saline (NSL 10ml/kg) control groups. Relative organ weights (ROW) of the liver and its enzymes (ALT, $A L P$ and AST) were evaluated 24 hours post treatments. Results showed a significant increase $(p<0.01)$ in ROW of the liver with MTX9pm-ART9am compared to MTX9pm. MTX9am showed significantly increased $(p<0.01)$ ALP compared to $M T X 9 \mathrm{pm}$. There was also significantly increased $(p<0.05)$ ALP in MTX9pm-ART9am compared to MTX9pm. In conclusion, the liver and its enzymes particularly the ALP were severely affected by day time administration of MTX and ART. The safety of these drugs may be improved with evening dosing.

Keywords: Artesunate, Chronomodulation, Liver enzymes, Methotrexate, Safety

\section{INTRODUCTION}

Chronopharmacology is the study of the manner and extent to which the kinetics and dynamics of medications are directly affected by endogenous biological rhythms. The temporal changes in drug effects include variations in both the desired (chrono-effectiveness) and undesired (chronotoxicity) effects. Chronomodulation must be designed to minimize the potential risk of drugs' adverse effects by taking into consideration the time of administration dependent toxicity (Cambar and Pons, 1997).

Methotrexate (MTX) is a folic acid antagonist that has been widely used for the treatment of leukemia, several other malignancies and many inflammatory diseases (Dalaklioglu et al., 2013). Clinically, hepatotoxicity remains one of the significant restrictions on its use in the doses desired (Jahovic et al., 2003; Cetinkaya et al., 2006). The dose and duration of treatment have been severely limited by the toxicity of the drug. The therapy with a high dose of MTX has become possible by the addition of leucovorin rescue regimens. However, the highly toxic effects of the drug are still a considerable problem. There is a significant circadian rhythm in these toxicity (Song et al., 1993).

Artesunate (ART) and other artemisinin derivatives have been demonstrated to be effective against various strains of malaria parasites (Maude et al., 2010) as well as tumor cell lines of leukemia and other malignancies (Efferth et al., 2001). There is no documented interaction between MTX and ART. Artesunate is instituted during the course of cancer chemotherapy when co-infection with malaria is established. Toxicity from these drugs might pose some challenges during the course of treatments. Despite intensive efforts in the management of the side effects of chemotherapy in patients and the development of chemo-protective agents, there is no generally accepted therapy at present (Verstappen et al., 2003).

Concurrent administration of MTX and ART being a clinical situation in cancer and malaria comorbidity, the study was therefore aimed at investigating the effect of chronomodulated ART on liver and its enzymes in MTX treated albino mice. 


\section{MATERIALS AND METHODS}

Animals:

Albino mice (18 - $23 \mathrm{~g})$ of either sex were obtained from the Animal House of the Department of Pharmacology and Therapeutics, ABU Zaria. The mice were maintained in a wellventilated room under room temperature and natural day and night cycle. They were fed on vital feeds and given access to water ad libitum. The mice were identified using a simple coded identification which was applied using concentrated picric acid solution.

Experimental design:

The mice were divided into six (6) groups (I-VI) of six (6) mice each. Group I, II, III, IV, V and VI were treated intraperitoneally with MTX 30 $\mathrm{mg} / \mathrm{kg}$, ART $30 \mathrm{mg} / \mathrm{kg}$ or NSL $10 \mathrm{ml} / \mathrm{kg}$ as either MTX9am, NSL9am, MTX9pm, NSL9pm, MTX9pmART9am or MTX9pm-MTX9pm respectively. Assessment was carried out 24-hours post treatment.

Serum analysis:

At the end of the experiment, all mice were weighed and sacrificed. The liver was removed and weighed. The relative liver weight was calculated as follows;

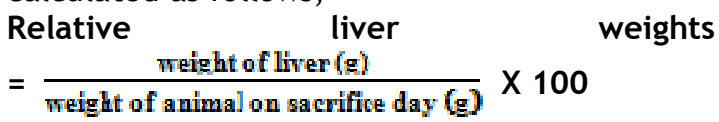

Blood samples from the jugular vein was collected from each mouse into sterile labeled plain sample tubes and centrifuged at $3000 \mathrm{rpm}$ for $10 \mathrm{~min}$ to obtain a clear serum using a centrifuge (Edewor et al., 2010). This was used for liver function analysis. Aspartate amino transferase (AST), Alanine amino transferase (ALT) and Alkaline phosphatase (ALP) were determined using colorimetric kits of analytical standard grades (Sigma-Aldrich, USA).

Statistical analysis

Results were presented as mean \pm standard error of mean (SEM) in tables. One-way ANOVA was used to determine significant differences between the groups followed by Bonferroni post hoc test using SPSS Version 22.0. $p \leq 0.05$ was considered statistically significant.

Results

Table 1 showed a significant increase in relative organ weight (ROW) of the liver in MTX9am compared to NSL9am $(p<0.05)$. Also, a significant increase with MTX9pm+ART9am compared to both NSL9pm $(p<0.05)$ and MTX9pm $(p<0.01)$ treated groups.

Table 2 showed that, co-administration of MTX and ART did not produce significant effect on the levels of AST and ALT. There was a significant increase $(p<0.01)$ in the levels of ALPs with MTX9am compared to NSL9am; also, MTX9am and MTX9pm+ART9am when compared to NSL9am and MTX9pm respectively. There was a significant increase $(p<0.01)$ in level of ALP in MTX9pm+ART9am treated group when compared to MTX9pm.

Table 1: Effect of Chronomodulated Artesunate on ROW of the Liver in Methotrexate treated Albino Mice

\begin{tabular}{|c|c|}
\hline Treatment Groups & ROW ( \pm SEM) \\
\hline NSL9am & $4.48 \pm 0.09$ \\
\hline MTX9am & $5.16 \pm 0.12^{*}, \#$ \\
\hline NSL9pm & $4.55 \pm 0.09$ \\
\hline MTX9pm & $4.78 \pm 0.12$ \\
\hline MTX9pm+ART9am & $5.11 \pm 0.11^{a, \# \#}$ \\
\hline MTX9pm+ART9pm & $4.38 \pm 0.06$ \\
\hline $\begin{array}{l}\mathrm{n}=8 ; \text { MTX=Methotre } \\
\text { ROW=Relative orgar } \\
\text { followed by Bonfer } \\
\text { NSL9pm; }{ }^{\#}=p<0.01\end{array}$ & $\begin{array}{l}\text { Iate } 30 \mathrm{mg} / \mathrm{kg} ; \mathrm{NSL}=\text { Normal saline } 10 \mathrm{ml} / \mathrm{kg} \text {; } \\
\text { of Mean. Data analyzed using One-way ANOVA } \\
\text { s. NSL9am; }{ }^{\sharp}=p<0.05 \text { vs. MTX9pm; }{ }^{a}=p<0.05 \text { vs. }\end{array}$ \\
\hline
\end{tabular}

Table 2: Effect of Chronomodulated Artesunate on Liver Enzymes in Methotrexate treated Albino Mice

\begin{tabular}{|c|c|c|c|}
\hline \multirow{2}{*}{$\begin{array}{l}\text { Treatment } \\
\text { Groups }\end{array}$} & \multicolumn{3}{|c|}{ Mean \pm SEM (IU/L) } \\
\hline & AST & ALT & ALP \\
\hline NSL9am & $8.25 \pm 1.19$ & $12.25 \pm 1.75$ & $111.63 \pm 0.98$ \\
\hline MTX9am & $10.25 \pm 1.31$ & $18.25 \pm 1.03$ & $197.38 \pm 1.71^{* *}, \# \#$ \\
\hline NSL9pm & $9.63 \pm 1.28$ & $12.38 \pm 1.32$ & $106.88 \pm 1.34$ \\
\hline MTX9pm & $9.75 \pm 1.10$ & $13.88 \pm 0.52$ & $119.25 \pm 1.65$ \\
\hline MTX9pm+ART9am & $10.63 \pm 0.76$ & $16.88 \pm 0.88$ & $179.13 \pm 1.70^{\mathrm{aa}, \# \#}$ \\
\hline MTX9pm+ART9pm & $10.75 \pm 0.70$ & $15.63 \pm 1.30$ & $120.38 \pm 1.51$ \\
\hline \multicolumn{4}{|c|}{ 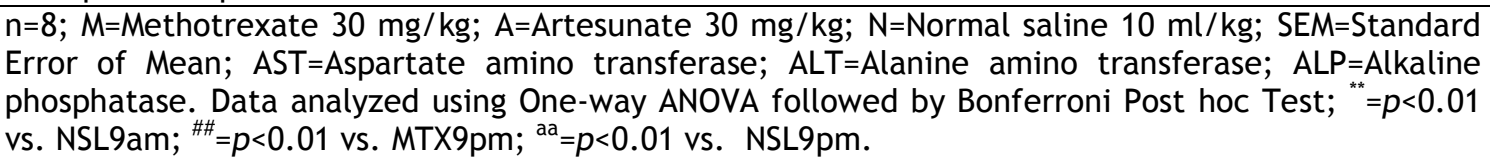 } \\
\hline
\end{tabular}




\section{DISCUSSION}

The study investigated the effect of time of administration of methotrexate (MTX) on liver and its enzymes. 9pm (MTX9pm) was identified as the time of MTX administration that produced least toxicity on the liver. To mimic the clinical possibility of concurrent use, artesunate was chronomodulated with MTX9pm to establish the possibility of altering its best time of administration. The significant increase in ROW of the liver with MTX9am $(p<0.05)$ and that with MTX9pm+ART9am was suggestive of inflammation/swelling of the liver, which is an indication of toxicity which necessitate caution especially in prolonged use. However, MTX9pm and MTX9pm+ARTpm produced less effect on the liver, and therefore the timely use of which could be encourage. Circadian dependent dosing time has been reported to influence the toxicity and efficacy profiles of many drugs in clinical therapy (Ohdo, 2003; Gachon and Firsov, 2011). The liver is involved in drug metabolism and detoxification, it undergoes some metabolic and morphological aberrations after the administration of many drugs.

The circadian variation of the hepatic defense system can alter the balance between the therapeutic response and the toxicity (Akhtar et al., 2002). Serum enzymes including Aspartate amino transferase (AST), Alanine amino transferase (ALT) and Alkaline phosphatase (ALP) are mainly used in the evaluation of hepatic

\section{REFERENCES}

Akhtar, R.A., Reddy, A.B. and Maywood, E.S. (2002). Circadian cycling of the mouse liver transcriptome, as revealed by cDNA microarray, is driven by the suprachiasmatic nucleus. Curr Biol. 12: 540-50.

Cambar, J. and Pons, M. (1997). Physiology and pharmacology of biological rhythms. Hand b Exp Pharmacol. 125:557-88.

Cetinkaya, A., Bulbuloglu, E., Kurutas, E.B. and Kantarceken, B. (2006). N-acetylcycteine ameliorates methotrexate-induced oxidative liver damage in rats. Med Sci Monit. 12: 274278.

Dalaklioglu, S., Genc, G.E., Aksoy, N.H., Akcit, F. and Gumuslu, S. (2013). Resveratrol ameliorates methotrexate induced hepatotoxicity in rats via inhibition of lipid peroxidation. Hum Exp Toxicol. 32: 662-671.

Deb, A.C. (1998). Fundamentals of biochemistry, 7th ed. Kolkata, India: New Central Book Agency. 12:57-88.

Edewor, T.I., Olajirea, A.A. and Usman, L.A. (2010). Effect of Oral Administration of Ethanolic Leaf Extract of Acanthospermum hispidium DC from Nigeria on some Selected Rat Kidney Enzyme Activities. Iranian Journal of Pharmaceutical Sciences, 6(4):283-287.

Efferth, T., Dunstan, H., Sauerbrey, A., Miyachi, H. and Chitambar, C.R. (2001). The anti-Malarial Artesunate Is Also Active against Cancer. International Journal of Oncology, 18(4):767773. damage. Their estimation in the serum is a useful quantitative marker of the extent of hepatocellular damage. This study showed that, co-administration of MTX and ART did not produce significant effect on the levels of AST and ALT. However, there was a significant increase $(p<0.01)$ in the levels of ALPs with MTX9am and MTX9pm+ART9am.

During hepatic damage, cellular enzymes AST, ALT and ALP present in the liver cells leak into the serum, resulting in increased concentration (Wu et al., 1990). The liver enzymes, ALT and AST are considered to be the most sensitive markers to assess hepatocellular damage due to liver cell necrosis (Deb, 1998). The circadian peak location coincides with the highest activity level which occurs during the dark span and food consumption of animals was established (William et al., 2004). The results of the present study showed some alterations in these hepatic variables. The ROW and liver function test suggest the evening dosing of MTX and ART to be the best tolerance.

\section{CONCLUSION}

In conclusion, the liver and its enzymes particulary the ALP were severely affected by day time administration of MTX and ART. The safety of these drugs could be improved with evening dosing. The dosing-time is therefore very useful in choosing the most appropriate time to administer medications.

Gachon, F. and Firsov, D. (2011). The role of circadian timing system on drug metabolism and detoxification. Drug Metab Toxicol. 7: 147-58.

Jahovic, N., Cevik, H., Sehirli, A.O., Yegen, B.C. and Sener, G. (2003). Melatonin prevents methotraxate- induced hepatorenal oxidative injury in rats. J Pineal Res. 34: 282-287.

Maude, R.J. , Woodrow, C.J. and White, L.J. (2010). Artemisinin Anti-malarials: Preserving The "Magic Bullet". Drug Development Research. 71(1):12-19.

Ohdo, S. (2003). Changes in toxicity and effectiveness with timing of drug administration: Implications for drug safety. Drug Saf. 26: 9991010.

Song, J.G., Nakano, S., Ohdo, S. and Ogawa, N. (1993). Chronotoxicity and chronopharmacokinetics of methotrexate in mice: modification by feeding schedule. Jpn J Pharmacol. 62, 373-378.

William, M., Lee, M.D. and Fa, C.P. (2004). Acetaminophen and the U.S. acute liver failure study group: Lowering the risks of hepatic failure. Hepatology. 40:6-9.

Wu, J.W., Lee, S.D. and Yeh, P.F. (1990). IsoniazidRifampicin induced hepatitis in hepatitis B carriers. Gastroentrology. 98:502-4.

Verstappen, C.C., Heimans, J.J., Hoekman, K. and Postma, T.J. (2003). Neurotoxic complications of chemotherapy in patients with cancer: clinical signs and optimal management. Drugs. 63:1549-63. 